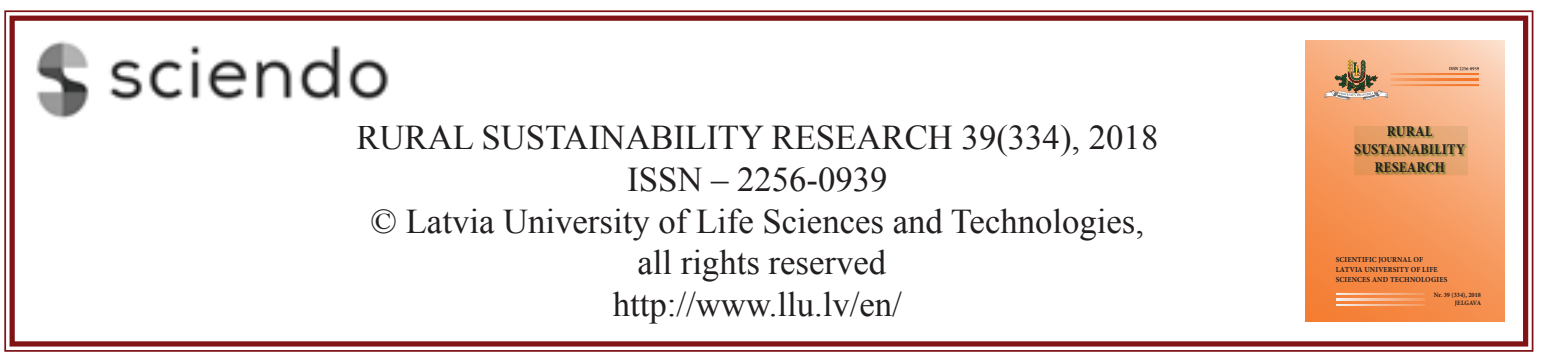

\title{
Trends of Lithuanian Cultural Landscapes in the Recreational Territorial System of the Southeast Baltic Sea Region
}

\author{
Jonas Abromas, Petras Grecevičius*, Aurelija Jankauskaite, Nijolė Piekienė \\ Klaipēda University, K. Donelaičio sq. 5, LT-92144 Klaipēda, Lithuania
}

\begin{abstract}
Southeast coast of the Baltic Sea area, Lithuania, Latvia and Kaliningrad Region of the Russian coastal habitats was very intense, often chaotic variety of recreational facilities and areas of privatization and urbanization. These processes significantly influenced the character of the recreational landscape of Palanga, Jurmala and other resorts and coastal areas, as well as the expression of the urban structure and architecture of seaside towns, Ventspils, Liepaja, Giruliai, Melnragè, Karklè, Šventoji, Curonian Spit and other settlements. After a quarter of a century, some tendencies of the recreational environment and the evolution of the cultural landscape identity can be noticed. Recently, several projects for the improvement of recreational infrastructure and architectural environments have been implemented in Lithuania with the assistance of the European Union Structural Funds. Unfortunately, the results of the projects are not always positive. The planning of coastal settlements is often overlooked by good long-term planning experience. This article analyses the impact of changes in the quality of the Lithuanian recreational territorial system in the SouthEastern Baltic and the region's recreational potential. Palanga resort areas dominated by architectural chaos and recreational quality of the environment tended to deteriorate, especially experts poorly assessed the central Basanavičiaus street. The changes in cultural landscapes are influenced by a whole range of methodological and practical factors: insufficiently effective research and modeling methods, unjustified privatization of state property, huge flows of individual automobiles, faults in the formation of recreational greenery. Based on the research of the recreational system of the coastal region of the long-term seaside, it can be concluded that in recent years the quality of the environment of many coastal zones of Lithuania has lost important qualitative components, deteriorated the quality of public spaces and increased urban and architectural chaos.
\end{abstract}

Keywords: territorial system of recreation, identity, urban development, cultural landscapes.

\section{Introduction}

1991-2017 the Southeast coast of the Baltic Sea area, Lithuania, Latvia and Kaliningrad Region of the Russian coastal habitats was very intense, often chaotic variety of recreational facilities and areas of privatization and urbanization. These processes significantly influenced the character of the recreational landscape of Palanga, Jūrmala (Figure 4) and other resorts and coastal areas as well as the expression of the urban structure and architecture of seaside towns: Ventspils, Liepaja, Giruliai, Melnrage, Karklè, Šventoji, Curonian Spit and other settlements. After a quarter of a century, some tendencies of the recreational environment and the evolution of the cultural landscape identity can be noticed. Recently, with the help of the European Union Structural Funds, a number of projects for improving recreational infrastructure and quality of the countryside have been implemented. Sadly, the results of the projects are not always positive. During the spontaneous formation of the Lithuanian maritime metropolis state of the quality of environment and landscape resulted in the loss of sustainability.

The seaside habitat is characterized by a unique and also very vulnerable landscape, rich in natural and cultural resources. The sea and its coastal recreational capabilities have had and still have a great impact on the lives of people in our country.

During the last twenty-five years, very intense and often unbalanced urbanization processes took place along the seaside, which led to the loss of the recreational potential of Palanga and Neringa resorts

\footnotetext{
* Corresponding Author's email: petras.grecevicius@gmail.com
} 


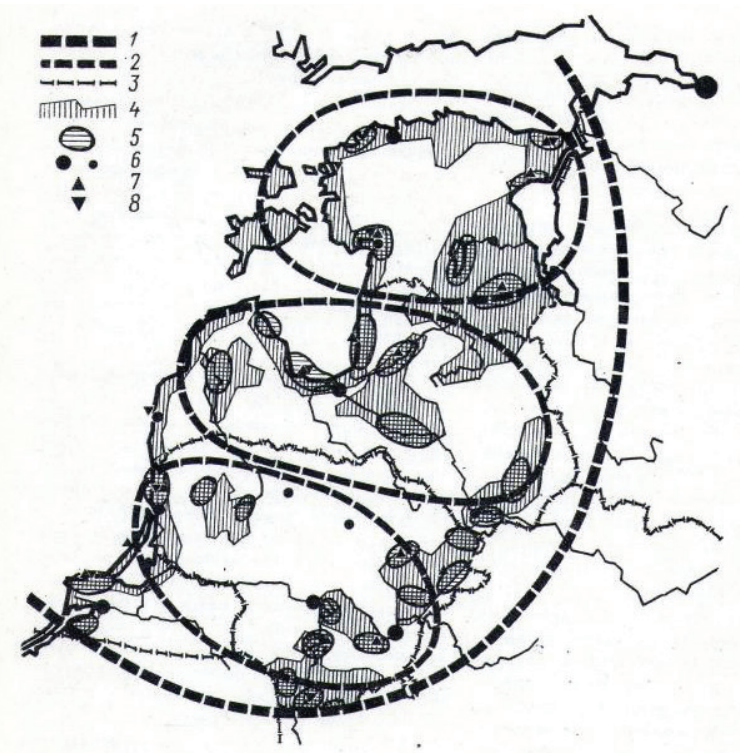

Figure 1. Recreation territory system of the Baltic region. (Stauskas, 2006).

as well as Giruliai, Melnrage, Kintai and other recreational areas. The Lithuanian marine metropolis is emerging in the seaside (Figure 1); the development of the Klaipeda seaport is accelerating; it is also expected to begin the reconstruction of Šventoji seaport; traffic flows are intensifying; and finally, environmental, landscape and especially marine coastal protection problems are exacerbating (Atienè \& Grecevičius, 1997).

The aim of research: To determine the trends in the development of the Lithuanian seaside recreational areas, the awareness of which would help to ensure sustainable use of the coastal zone and the mainland areas, and allow the public to use seaside recreational resources more efficiently and to preserve the unique landscape of the Curonian Spit and the mainland coast. $1991-2017$ year period recreational landscape development experience and potential analysis of the South East Baltic considering neighboring countries (Estonia, Latvia, Russia and Poland) coastal territorial recreational systems are relevant for the follow-up projects and organizing recreation.

Important coastal recreation potential trends in the study are:

1. Determine the status of the coastal beaches trends and priorities, indicating the coastal zone and the continental region (the western region of Lithuania) management decisions; discuss

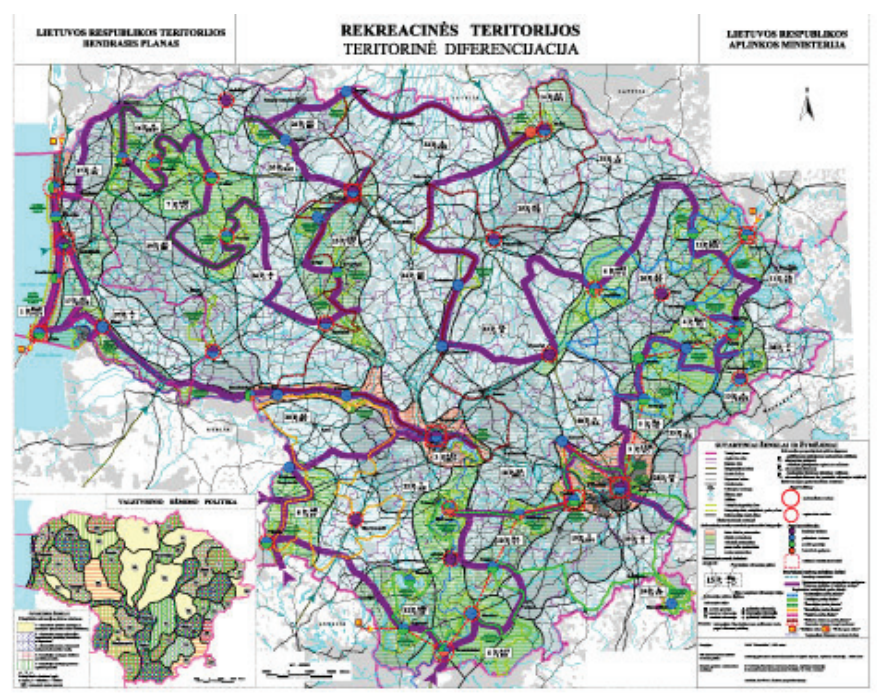

Figure 2. Lithuanian Territory Plan. Recreational areas. (2002 m.). 
the priorities for the use and management of seaside beaches and the rules for the protection and management of recreational resources and landscapes.

2. To envisage principles for the formation of recreational infrastructure in the seaside landscape; to define the structure of public recreational infrastructure network providing for the concept of the distribution of recreational infrastructure for public visits and other infrastructure objects.

3. To meet the public needs by protecting the seaside landscape and recreational resources, and by ensuring sustainable development of the area; to harmonize the interests of the country by developing seaside tourism and recreational services.

\section{Materials and Methods}

In the paper, Klaipeda University of Architecture and Urban Design Center for the coastal region of cultural landscapes research material and the author's personal scientific archives were used. The following methods were used: system analysis, comparative analysis, visual inspection of the recreational green spaces and environmental assessment studies of the structures, including the methods of spatial structure analysis of recreational landscapes (Lynch, 1981).

The study is based on the results 1991-2017 in Lithuania. According to the solutions of the general plan of the territory of Lithuania (Figure 2), the seaside territory is attributed to high and to very high potential recreational areas of national importance.

The general plan of the territory of the Republic of Lithuania provides the guidelines for the development of recreational seaside region. Thus, the medium and high quality infrastructure for accommodation and the base of recreational services must be created. Undoubtedly, Palanga must remain the main resort of the Lithuanian seaside (Lietuvos Respublikos teritorijos bendrasis planas, 2002; Palangos miesto bendrasis planas iki 2015 metų, 2008).

\section{Results and Discussion}

The Lithuanian seaside recreational region plays an important role in the whole area of the Southeast Baltic Sea tourist habitat. The seaside and especially the seaside strip are full of areas and objects of great recreational value and tourist attraction. The area has two main climatic seaside resorts of the country with the most important preserved asset, i.e. non-urban and non-private strip of beach dunes.

During the summer, the Baltic Sea and its beaches become a major tourist attraction centre in Lithuania. Up to 350 thousand guests (holidaymakers, tourists, excursionists) can be accommodated here at a time. Large visitor flows are attracted by thematic tourist routes and roads, which are under formation (Mickevičius \& Žilinskas, 2000). Unfortunately, many great ideas went unsuccessful, such as the

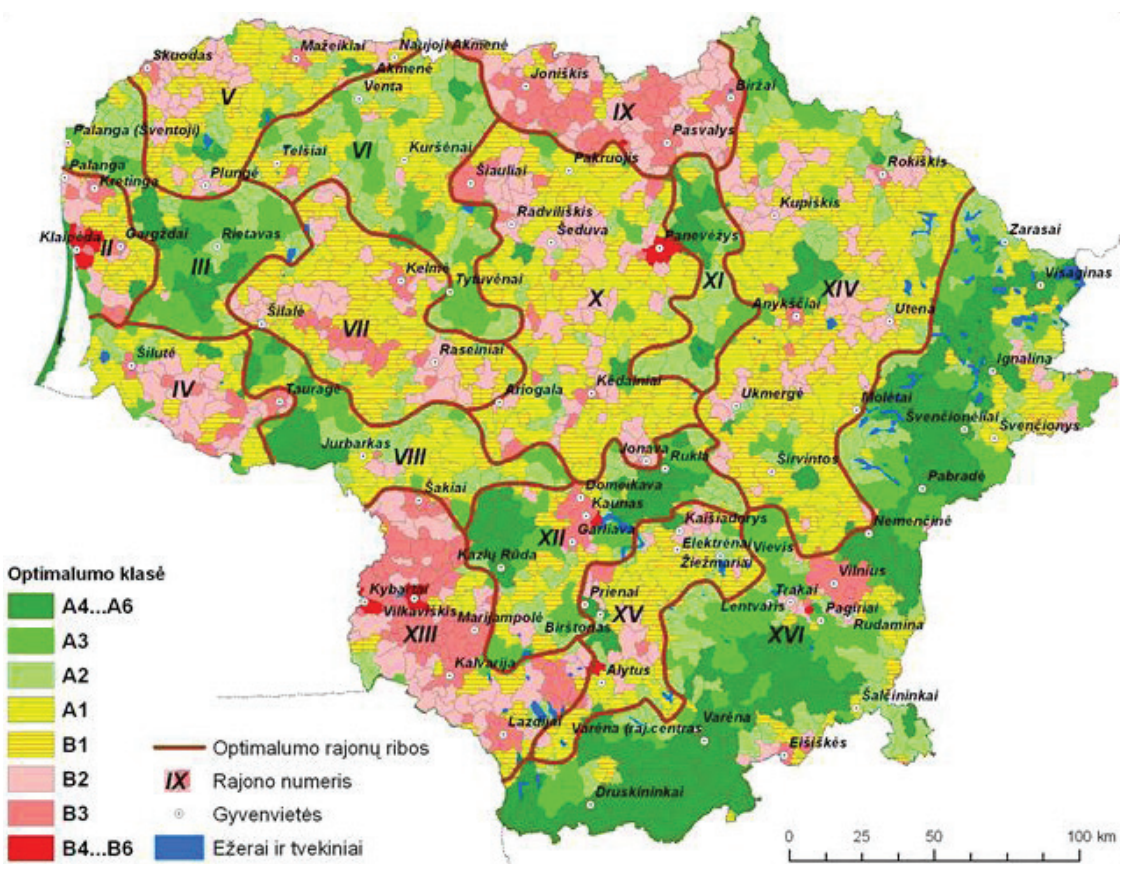

Figure 3. Territorial distribution of landscape structure optimality classes and optimal districts (Kavaliauskas, 2013). 


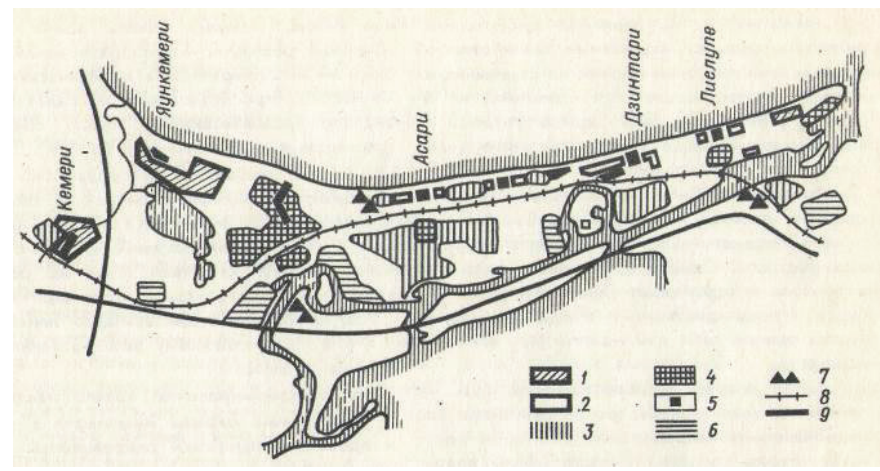

Figure 4. Jūrmala resort general plan. Architect A.Titmane (Stauskas, 2012).

Amber Road, the Curonian Culture Path; the development of a small cruise tourism ring had stopped without starting; no special attention is paid to the creation of auto-tourism and thematic parks. The development of recreation in seaside forests is limited by the forestland status. Even spontaneous beds, which are currently grown together in the area of the former Giruliai Park (which existed before the War) are ascribed to forests. The possibility of the formation of recreational complexes is also difficult in the Seaside Regional Park area.

It is very important to have a chance to be near the sea in a quiet natural environment with a large variety of recreational activities, and the combination of water, dunes and pinewoods. The area is still rich in natural recreational resources: sea basins, seaside beaches, a unique natural non-urban strip of seashore, recreational forests, and clean ionized air (Grecevičius, 1982).

Unreasonable restitution of land by small 20 -acre plots has done irreparable damage to the formation of the sustainable seaside recreational territorial system. Building a larger object on the plot of such a size is impossible; meanwhile, land consolidation possibilities are very limited.

While analysing the development of the formation of the Lithuanian seaside recreational use and the territorial system, it is necessary to evaluate the reasons for deviating from the "nest" idea to localize seaside settlements in the mainland area during the research period (Figures 5 and 6).

The Great Palanga stretches along the unique natural environment, the main factor of which is the sea and the associated natural components (Figure 6).

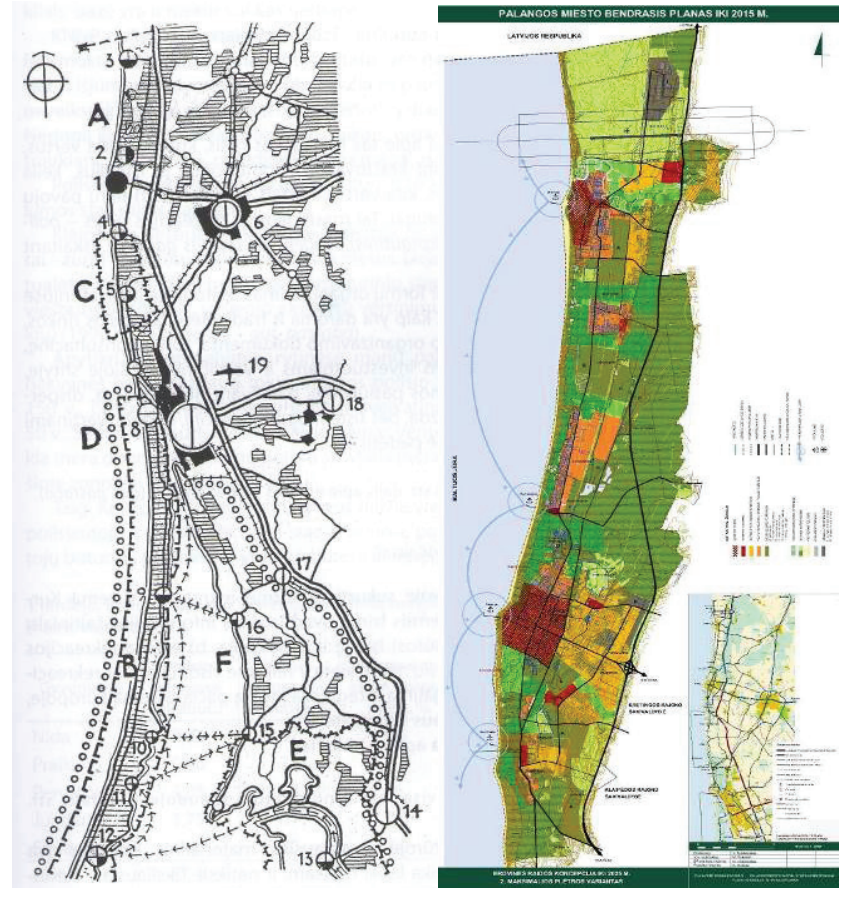

Figure 5. „Deep - nest” concept is barely seen in the Master Plan of Palanga Resort 2008. 


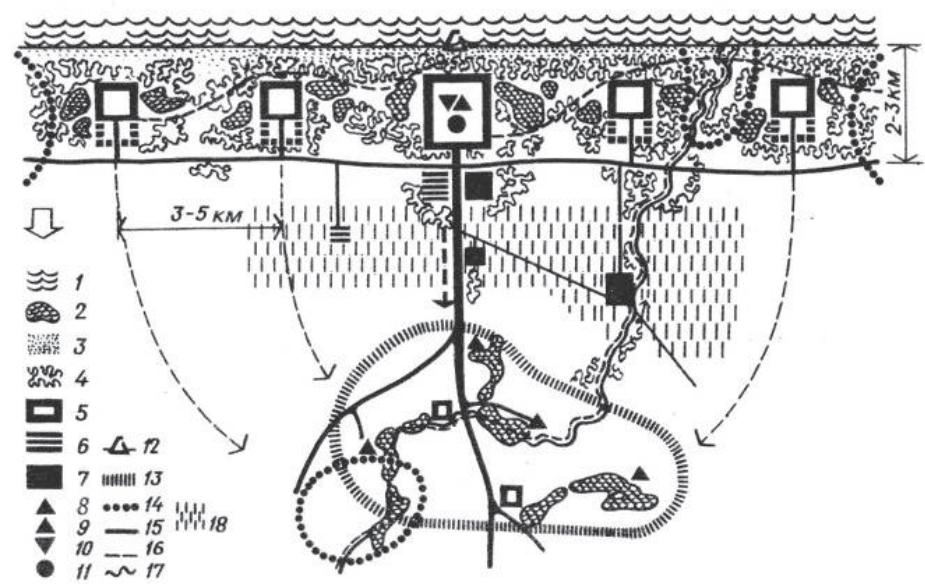

Figure 6. „Deep - nest” conceptual model of the seaside planning (Stauskas, 1968).

However, the resort still has no complete urban structure. The future of Palanga urban development depends on the idea of urban frame (Stauskas, 2012), and further trends in the development of recreation economics.

An interesting practice of recreational seaside complex is observed in Vanagupe. The primary architectural idea of Vanagupe recreational complex was based on the analogue of the urban structure of the Old Palanga historic villas (Figure 7). The aim of the authors was to prevent the structures from invading roughly into the coastal zone visual field. The aim was to preserve the sense of naturalness, purity, long-term stability and security. The intention was to prevent the structures from dominating over the green line of the coastal dunes, instead the original architecture verticals should have been visible in certain areas (Figure 6).

Undoubtedly, the development of the seaside recreational territorial system is recently influenced by Klaipeda city with quite a large unused recreational potential. The city still has a good natural basis for thematic parks. However, turning the former popular Giruliai and Melnrage resort settlements into the blocks of dwelling houses of Klaipeda city is deemed negative.

The number of violations of sensitive spaces of the Curonian Spit and Palanga resorts is increasing, since new buildings and small architectural objects of questionable aesthetic value rise in Juodkrante and Nida. Erection of elements, not typical for Neringa, Palanga and Klaipeda historic environment, has a negative impact on recreational environmental culture. The number of stationary bed places in Palanga and Neringa resorts has relatively decreased by 2-3 times comparing with 1990 . The territorial system of recreational services is unbalanced.

The following indicators can be evaluated while analysing the development possibilities of the seaside recreational territorial system:

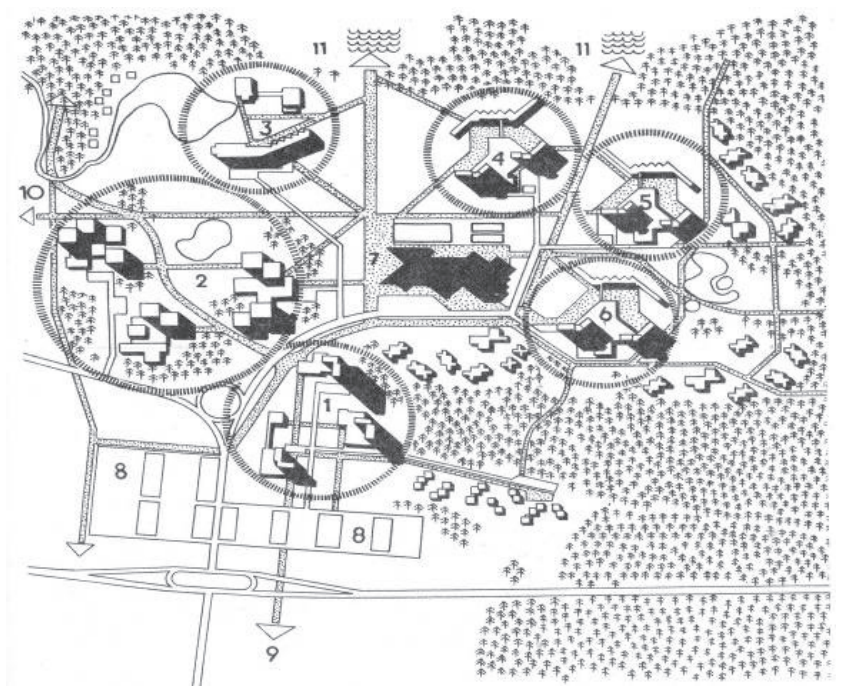

Figure 7. Vanagupè recreational complex project. Arch. Leckas, 1973. 
1. The area's recreational cultural and natural resources. The impact of natural resources on the recreational use of the area is analysed by three aspects: suitability of the beach morphometric parameters (beach width and slope) and sandy texture for recreational activities; the impact of the area's hydrographic regime on the formation of recreational spaces, and the possibilities of using the hydrographic network for the development of recreational infrastructure; resistance of beach and protective beach dune ridge vegetation, and seaside forests to recreation, and possibilities of using them for the formation of recreational spaces. The impact of cultural heritage on recreation development is analysed from two aspects: possibilities of recreational development, and restrictions on the status of the cultural heritage area as well as adaptation of cultural heritage objects for the development of recreation and tourism.

2. Intensity of current use of the area. The assessment of current use of the area; current visitor flows; suitability of the area's recreational space for the spread and flow of visitors; the impact of visitor flows on the natural environment; and the need for regulating visitor flows.

3. Current infrastructure. Transport infrastructure was analysed in terms of communication by motor (car parking lots, etc.) and motorless vehicles, on foot, and the existing access roads to the sea. The number and distribution of information infrastructure (number and style of information stands), and recreational (beach) infrastructure (rescue stations, changing rooms, benches, bins, containers, toilets, beach sports and children playgrounds, food, drinking water fountains, smoking areas, inventory points, stairs to the beach) was also analysed.

4. Conflicts arising from incompatibility of land use demand and supply. For this purpose, the main demand and interest groups for using the coastal zone mainland have been determined, and their spatial distribution was analysed; the territorial conflict habitats have been distinguished.

The following functional zones have been distinguished according to the existing recreational activity:

- Beach centres for recreational services areas near the corridors of visitor flows with adjacently developed recreational services, entertainment, etc.;
- Recreational areas of intensive use, which are coastal stripes, where the volume of recreational activities is the highest compared to the recreational capacity.

Proper compatibility of activities is important in planning seaside recreational areas. The assessment of recreational properties of the Lithuanian seaside mainland beaches includes distinguishing of seaside stripes, which are different in their morphological and geomorphological characteristics, and their management properties, i.e. their attribution to administrative formations. The analysis of the conditions of natural continental seaside beaches included seaside stripes of Klaipeda city, Klaipeda district, Seaside Regional Park (Klaipeda district part) and Palanga resort.

The total length of the entire mainland seaside strip from the northern pier of Klaipeda to LithuanianLatvian border is about $38.5 \mathrm{~km}$. The beach width ranges from 15-25 m (at the Dutchman's Cap Cliff) to $90 \mathrm{~m}$ (the southern part of Šventoji settlement). The approximate area of the beaches from the northern pier of Klaipeda to Lithuanian-Latvian border is about 155 ha. In that area about 240 thousand visitors can have rest at a time, if that area is properly fixed.

The social aspect of the use and development of the Lithuanian seaside recreational resources.

Recently, the significance and importance of the social aspect and the aspect of people's needs is stressed in many fields of activities, especially in relation to the environmental planning (Figure 8). Common technical, economic, ecological and aesthetic grounds are increasingly related with the sociological grounds (Vanagas \& Neniškis, 2000). The Lithuanian seaside occupies an important place in the development of the national economy, recreation and tourism; it has a unique and vulnerable landscape, as well as abundant natural and cultural resources. This area is ascribed to the recreational range group of a very high potential. It is suitable for the development of many types of recreation (cognitive, sports, entertainment and therapeutic) and tourism.

However, the state of some seaside areas is special for its natural environment greatly suffering from large unsettled recreation flows. The forestry area is full of trails. In some places, the forest is soaked due to unhandled stream and stormwater. Visitors bypass the swampy areas, thus making new trails, which results in the loss of forest floor. Seaside protective dunes are eroded not only by the sea waves and wind, but also because of unhandled flows of recreationists' movement to the beach. Therefore, there is an urgent need to develop a complex of measures for handling and managing 


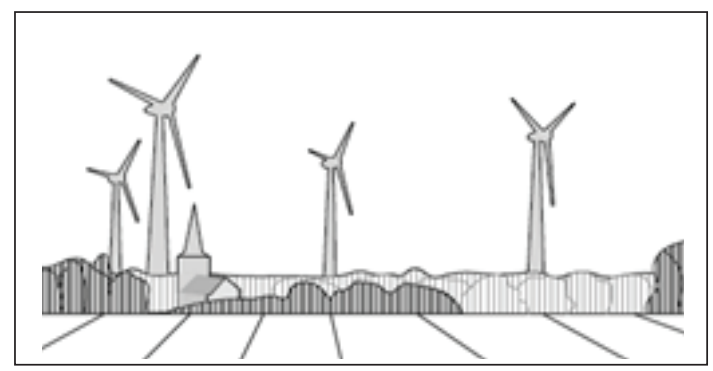

1

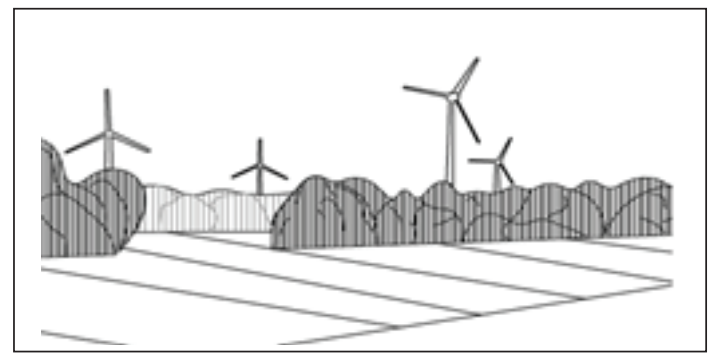

2

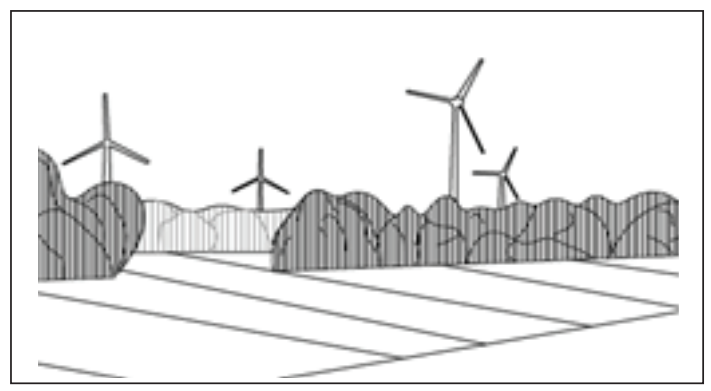

3

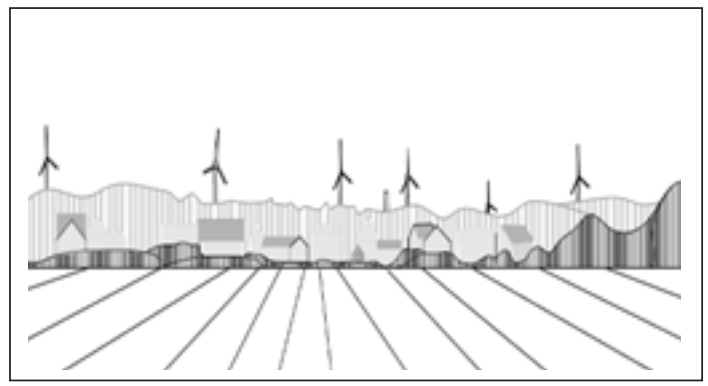

4

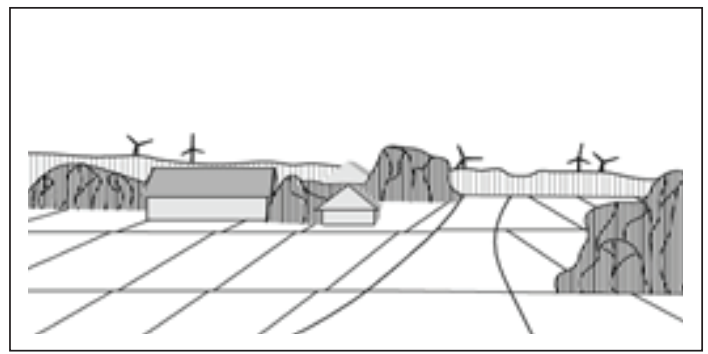

5

Figure 8. Diagrams of the significance of the impact of the wind turbines in terms of degrees:

1 - visually dominating, 2 - generally dominating, 3 - accents, 4 - subdominants, 5 - background elements (Abromas et al., 2013).

recreational areas, which would ensure the ecological stability of the areas' natural environment, and would preserve principal recreational values (Jahrbuch der Hafenbautechnischen Gesellschaft, 2004; Jarmalavičius \& Žilinskas, 2007).
New factors for the visual impact on recreational areas.

The time period 2006-2017 in Lithuania and Latvia, in the coastal region is characterized by erection of wind turbines, which have a huge impact 
on the cultural landscape. The article analyzes some aspects of this effect. The assessment of the landscape was carried out using an original methodology for evaluating architectural spaces (Abromas et al., 2013).

Connection transmission and energetics systems are becoming inextricable part of landscape of which the most important ones is overhead power transmission lines, signal towers, wind turbines. Shape and scale of it makes strong contrast with natural landscape. Overhead power transmission lines is classified as horizontal (linear) landscape object, electricity poles, connection transmission towers and wind turbines - vertical landscape objects. Noted objects isn't only very noticeble in the landscape, but also changes it. It is common in Western part of Lithuania, where number of wind turbine parks is bigger and also building new overhead power transmission lines.

Wind turbines are becoming an integral part of the landscape in Western Lithuania. The hub height of the wind turbines currently under construction reaches $75-150 \mathrm{~m}$, while the blade-tip height is $150-200 \mathrm{~m}$. Wind turbines can be visible from up to $25-30 \mathrm{~km}$ distance. Their construction in the area is initiated by the average annual wind speed, reaching 6-7 $\mathrm{m} \mathrm{s}^{-1}$.

Although this region has important resorts, protected areas, intensive tourist routes. Also, quite often problems arise when wind turbines are built in the area of natural framework, in the approaches to the national and regional parks, near the important site of cultural heritage and their visual protection zones, and villages. Due to these aspects, the valuable landscape has changed in some areas, since the future impact of the wind turbines under construction had not been adequately estimated.

High voltage overhead power transmission lines $(35 / 110 / 330 \mathrm{kV})$ is an important element of agrarian landscape. These transmission lines form straight routes and it is almost imposible to mask it. In this case it is important how it looks, also the value of landscape and the background. Overhead power transmission lines situated in flatlands, roadsides, by the railroads, link all together in united linear components.

Suggestion is (if it is technically possible) for owerhead power transmission line wires undulation to recul the location hilliness to reduce presumably negative overhead power transmission lines visual impact on the landscape. Also, it is recommended not to build electricity poles on the highest points of relief, river and pond slopes.Furthermore, less loll wires net suits better in flatlands.

On assessing the importance of the roads in situ, the importance of the impact of the wind turbines was grouped in terms of degrees (Figure 8):
1. Visually dominating (about $0-1 \mathrm{~km}$ ). Wind turbines dominate in the observation area due to their bulky size. Essentially change the sight of the neighboring environment. The movement of the rotor is clear;

2. Generally dominating (about $1-3 \mathrm{~km}$.). The turbines look bulky and are a significant element of the landscape; however, they do not necessarily dominate in the observation area.

3. Noticeable (accents) (about 3-7 km). Wind turbines are clearly visible, but they aren't visually unwanted any more. The movement is noticeable at good visibility. The turbines do not look large in the overall field of view. Some changes in the landscape due to the emergence of the turbines are acceptable. The observation is influenced by weather conditions;

4. Subdominants (about 7-10 km). Wind turbines are less clearly visible, the size is visually diminished, but the movement is noticeable. With the increasing distance, wind turbines become general elements of the landscape;

5. Remote elements of the landscape (background elements) $(>10 \mathrm{~km})$. The turbines are no longer clear, of a small shape and look insignificant. The movement of the blades is generally unnoticeable. The overall size of the turbines is very small (authors of the article and Jallouli, Moreau 2009).

The uniqueness of the area lies in the fact that it entails the aspects of meeting the locals' recreation needs, and also because it serves as a short-term and holiday recreation place for the entire Lithuanian population.

The emerging Klaipeda marine metropolis also has quite a clear development trend, influencing the priority strengthening of the planned area's recreational function. A great potential of recreational resources lies in Giruliai - Melnrage seaside strip, but the natural environment is suffering greatly from unregulated recreation flows and unhandled surface waters. During the pre-war period, this area was used for intense recreational activities; it had park spaces and villas. This is an important factor influencing the further vision of the land usage.

The greater part of this area (about $70 \%$ ) is currently used as forestland. In the perspective, the whole area should be transferred to the Klaipeda City Municipality, allowing it to develop intensive recreational activities.

The area is being developed as an extremely important recreational zone of Klaipeda city, attracting high numbers of locals and people from other regions not only in summer but also in other seasons. In this area, the main short-term and long-term recreational 
needs of people are associated with priority use of the recreational area, which in turn is related to the quantitative, qualitative and diversification increase of the area's recreational capabilities, and the development of adequate service infrastructure.

The following steps should be taken for the Lithuanian seaside recreational territorial system to reach its full potential and qualitative development with the help of integral and effective use of natural and cultural resources:

1. To prepare a special plan of the recreational territorial system of the South-Baltic coastal region. It should discuss the issues of the integrity and identity and preservation and consolidation of the cultural landscapes of the recreational territories of Lithuania, Latvia, Russia and Poland. It is planned to evaluate the good experience of neighbors, to create a unified view of the state of the South-Eastern Baltic cultural landscapes, the protection of values and the formation of a spatial model.

2. To ensure the best protection and development of natural and cultural resources of the coastal region (Klaipèda Old Town, Neringa and Palanga resort, seaside dune park strip with beaches). Perform regular surveys of the marine landscape and forecasts of its changes.

3. Seek formation of marine tourism and tourism infrastructure in South East Baltic Sea and the Curonian Spit as soon as possible. (Marine yacht port construction, Giruliai entertainment island, the small Gulf ports, marine pier Juodkrante and Nida), integrating it into a cross-border territorial recreational system.

4. Regular systematic marine coastal research and management work carried out by a specially established public science company. Dune management should be transferred to foresters.

5. Develop a program for the conservation and maintenance of recreational resources for the coastal zone of Klaipeda and the Baltic Sea coast and other coastal zones as well as an action plan for effective use.

6. Initiate recreation zone development and management as a priority for coastal urban recreation, sports and entertainment part; to create high quality facilities for the recreational facilities for visitors. Develop recreational service centers, rescue stations, and install 24-hour toilets with the necessary engineering networks.

7. Significantly improve the visitor recreation services in a variety of nature to maintain a stable framework for the existing natural landscape features and strengthen the elements that restore and maintain the natural landscape; to substantially increase the quality of the recreational area through the development of amusement parks, such as the Baltic Sea Ethnic Culture Forest Park, planned for the Baltic Sea Region's coastal area.

Conceptual provisions of the landscaping and its management are aimed at ensuring recreational attraction, aesthetic value, recreational capacity and ecological stability of the planned area (Lietuvos pajūrio region..., 2007). The protection of natural (greenery, dunes, water resources, marine landscape, amber, i.e.) and cultural resources and their rational use for cognitive and recreational purposes as well as sustainable economic activity are combined harmoniously. Natural resources and forests are handled to provide people with health benefits, instead of protecting them (Lietuvos Respublikos pajūrio juostos istatymas, 2002). Little cultural heritage values have remained in the seaside areas, but the nature of the use of part of areas is adjusted in principle under the basis of the pre-war urban structure.

Strengthening of the landscape identity and cultural as well as natural authenticity is impossible without a clear and reasonable concept, the most important provision of which is the protection of the environment through the creation and use of new higher quality landscape values, and timely response to the ever-changing world.

The basic principal provision of the seaside recreational territorial system of landscaping is to create a silhouette of modern and sustainable marine region, which can be observed from the sea, by shaping natural - urban hills as highlights of green coastline in the visual zone of Giruliai, II Melnrage, Melnrage, Karkle, Nemirseta, Palanga, Šventoji, etc. The most important observation decks for the seaside area are located on the back platform of the northern pier of Klaipeda and Palanga Sea Bridge.

The pursued indicator of optimality (quality standard) of natural and urban landscape structure of the emerging area is a consistent transition from urban to natural space without extensively bright contrast. Integrity principle typical of resorts or resort areas is applied to the urbanized and natural landscape ratio.

The research resulted in the statement that due to some constructed objects the quality of some seaside territorial landscapes is diminishing, singularity is under loss and emotional impact is weakening. The process of the formation of the harmonious recreational territorial system and representational landscape framework requires adjoining of the protected territories, resorts, recreational spaces, and 
values of cultural heritage into united complexes. But the reality of territorial planning is that the main objectiveness is given to division into the plot areas and the elementary urban logic of the development of recreational territories is discarded. Within the settlements, public spaces are rapidly diminishing and disappearing, green areas suffer from intensive urbanisation, previously planned parks and squares are losing their planned land sites. After the privatisation of the central part and approaches to the port of Šventoji, the ability of old port reconstruction was lost.

The territory area of Great Palanga still consists of some exceptionally valuable natural landscape complexes that must be protected from privatisation. Those include Šventoji geomorphological structures, the dune park forest of Kunigiškiai, the river side park of Šventoji, recreational forests of Palanga, Nemirseta and Šventoji.

\section{Conclusions}

1. After the restoration of Lithuania's independence, urban development on the seafront has acquired new features. In 1995, a system of protected areas was created: the Curonian Spit National Park, the Seaside Regional and the Nemunas Delta Regional Parks. Subsequent Natura 2000 sites were identified. In order to protect the seaside protection strip from the building, it has been approved. In 2000, the status of the World Cultural Heritage was granted to the Curonian Spit. Similar systems of protected areas were formed in Latvia and in the Kaliningrad region of Russia. In part, such protection measures for cultural landscapes proved to be successful.

2. In the place of the former departmental recreational establishments, the residential areas or homegroups of the temporary residents were formed upon privatization, and some of them became hotels or SPA. This has negatively affected some of the less affluent population's ability to arrive in the summer for recreational purposes by the sea. The sanatorium network developed in the Soviet era decreased. After the destruction of the former bases of pioneering camps, there was no alternative to securing the rest of the children by the sea. There are pedestrian streets and bike trails, but the areas and streets of the resort and other recreational areas are filled with an extensive traffic flow.

3. UNESCO granted the status of the cultural heritage of the World to the Curonian Spit National Park as a guarantor of its protection against the urban development, provided the opportunity to handle work with the help of scientists, but due to insufficiently logical solutions to the general plan, the development of recreational services became more coherent. The dangers of the disappearance of natural landscapes, the great dunes, and the problematic situation in the massif of mountain peaks occurred previously.

4. Demographic structure problems are increasing. In 2000, the number of permanent residents in the Palanga resort was projected to grow to 24 thousand, while in fact there are only about 17 thousand. Similar quantitative tendencies of the indigenous population are found in other Lithuanian seaside settlements as well as ones at the Latvian seaside.

5. Characteristic features of the development of the seaside cultural landscapes: architectural and urban chaos, legal nihilism, neglect of the needs of the greenery system, unambiguous arrangement of recreational service objects. In Klaipeda, Palanga resort and other seaside settlements, there is a lack of architectural harmony, disrespect for cultural heritage values. The most important historical values of Palanga dallies, some of the old villas, have been practically destroyed. In the context of the protection of cultural heritage, a better situation in the seaside settlements of Latvia.

6. In the time period from 1995-2015, the accelerating urbanization process in the course of Palanga resort planned structure of the deepnested turned into linear. This was determined by the disposition of the engineering communications and the ignorance of some of the existing or potential elements of the greenery system. Previously planned parks no longer have space. Recently, urban planning and architectural planning work is carried out without adequate research into the qualitative development of the recreational environment; there is no need to focus on the formation of dune parks, stabilization of the sea coast. Important research is not subject to budget funding.

7. Southeast Baltic territorial recreational system of sustainable development can be a creative collaboration from Lithuania, Latvia, Poland professionals to share experiences, research material. The uniqueness and identity of the cultural landscapes of the main regions are needed to ensure the uniqueness and identity of the cultural and historical landscapes of the main regions. This, in turn, will ensure the 
attractiveness of the recreational territorial systems, without which it is impossible to develop the tourism and recreation industry effectively.

\section{References}

1. Abromas, J., Grecevičius, P., Genys, J., Pridotkienè, L., Marčius, R., Dubra, V., Urbonienė, R., Olšauskas, A. M., Dučinskienė, E. (2013). Urbanizuoto kraštovaizdžio analizès ir vertinimo metodika. (Methodology for analyzing and evaluating urban landscapes). Klaipeda. 100 pp. ISBN 978-9955-18-720-2. (in Lithuanian).

2. Atienè, V., Grecevičius, P. (1997). Rekreacinès aplinkos architektūros formavimo tendencijos ir problemos Lietuvos pajūrio regione (Trends and problems in the formation of the recreational environment in the Lithuanian seaside region.) Town planning and architecture. No. 2 (24). V. Technika, pp. 60-66. (in Lithuanian).

3. Grecevičius, P. (1982). Pabaltijo kurortuc rekreacinių paslaugų sistemų architektūrinis planinis organizavimas. Daktaro disertacija. (Architectural planning of recreational services systems in the Baltic resorts. Doctoral dissertation.) pp. 48-64. (in Lithuanian).

4. Jahrbuch der Hafenbautechnischen Gesellschaft. (2004). (Coastal Protection - State of the Art Future Perspectives in Germany). 54. Band. Hamburg, pp 321. ( in German).

5. Jallouli J., Moreau G. (2009). An immersive path-based study of wind turbine landscape: A French case in Plouguin. Denmark. Renewable Energy 34, pp. 597-607.

6. Jarmalavičius, D., Žilinskas, G. (2007). Lietuvos žemyninio jūros kranto paplūdimių technologinis tinkamumas rekreacijai. (Technological suitability of recreation for the beaches of the mainland of the Lithuanian continental shelf), Annales Geographicae 1 (40), ISSN-1822-6701. pp 28-37. (in Lithuanian).

7. Kavaliauskas, P. (2013). Lietuvos Respublikos kraštovaizdžio erdvinès struktūros įvairovès ir jos tipu identifikavimo studija. II dalis. (Study of the diversity of the spatial structure of the landscape of the Republic of Lithuania and its identification. Part II.) Vilnius University. ISBN: 9786094170645. pp 36. (in Lithuanian).

8. Lietuvos pajūrio regiono turizmo plètros studija. (Tourism Development Program of the Lithuanian Seaside Region) (2007). Vilnius. pp. 17-26. (in Lithuanian).

9. Lietuvos Respublikos Pajūrio juostos ịstatymas. (2002), (Law on the Seaborne of the Republic of Lithuania) No. 73-3091. pp. 1-4. (in Lithuanian).

10. Lietuvos Respublikos teritorijos bendrasis planas. (General plan of the territory of the Republic of Lithuania) (2002). No. IX-1154 pp. 53. (in Lithuanian).

11. Lynch K. (1981). A Theory of Good City Form. Cambridge, London. pp 77-99.

12. Mickevičius, V., Žilinskas, G. (2000). Baltijos jūros Lietuvos žemyninio kranto apsauginio paplūdimio kopagūbrio tinkamumas rekreacijai. (Suitability for recreation of the Baltic coat of the Baltic Sea coast of Lithuania). Geography Yearbook, 33, ISSN 0132-3156.pp 174-181. (in Lithuanian).

13. Palangos miesto bendrasis planas iki 2015 metu (Palangos miesto bendrojo plano koncepcija iki 2025 metu). (The general plan of Palanga city until 2015 (the concept of the general plan of Palanga until 2025)) 2008. pp 13. (in Lithuanian).

14. Stauskas, V. (2006). Pajūrio kraštotvarkos politika: kryptinga sistema ar dar ne? (Seaside Regional Policy: A Targeted System or Not?) Archiforma, Nr. 1 (33), pp. 57-64. ISSN 13924710. (in Lithuanian).

15. Stauskas, V. (2012). Architektūra, aplinka, atostogos. (Architecture, environment, holidays), Kaunas, 392 p. (in Lithuanian).

16. Vanagas, J. Neniškis, E. (2000). The potential of Lithuanian towns within the urban context of the Baltic sea region. Town Planning and Architecture Nr. 2 (24). V. Technika, pp. 47-59. 